\title{
INVASIVE SPECIES IN THE CONTEXT OF CLIMATE CHANGE: THE CASE OF MAGALLANA GIGAS (THUNBERG, 1793) IN THE BLACK SEA
}

\author{
Ana-Maria Krapal'1, Elena Buhaciuc-Ionițăª , Marian Ioniță², \\ Elena Iulia Iorgu ${ }^{1}$
}

\author{
1"Grigore Antipa" National Museum of Natural History, Bucharest, Romania, \\ e-mail: ana.krapal@antipa.ro, elenap@antipa.ro \\ "Natura-Z" Research and Education Society for Biodiversity Conservation, Constanța, Roma- \\ nia, elena_buhaciuc84@yahoo.com
}

\begin{abstract}
The current climate changes are having a significant impact on species distribution. While some species are affected, others are thriving in these new conditions, expanding their range. This is also the case of some invasive species who seem to benefit from these changes. The invasive Pacific oyster Magallana gigas is among these species. The current situation of the Pacific oyster in the Black Sea is discussed, with new data from the Romanian waters.
\end{abstract}

\section{Introduction}

The constant global warming trend has a great impact on the distribution of species worldwide. Some native species spread their areal, while others are greatly affected and are faced with extinction. The warming climate is also a favourable factor in the dispersal and acclimatisation of some invasive species to new habitats $[4,10]$.

Not many species can acclimate to the Black Sea conditions, but there are some species with a wide tolerance to salinity, temperature and $\mathrm{pH}$ that have been successful in these conditions. Among these species, the ones with the biggest impact on Black Sea ecosystems were the invertebrates Mnemyopsis leidyi, Rapana venosa, Mya arenaria, Anadara kagoshimensis etc. These species have managed to drastically impact the ecosystems on different levels: the ctenophore M. leidyi has seriously affected the zooplankton stock which led to the collapse of the planktivorous fish [11]; the veined rapana whelk $\mathrm{R}$. venosa is the one responsible for the disappearance of the native flat oyster Ostrea edulis [6]; the softshell clam M. arenaria has produced major changes in the benthic ecosystem by replacing the native dominant species Lentidium mediterraneum [5].

The most recent invasive species settled in the Black Sea is represented by the Pacific oyster Magallana gigas (Thunberg, 1793). Here we present the past several years status of an established population discovered in the Romanian Black Sea.

\section{Matherials and methods}

A small wild population of M. gigas was discovered in 2017, in Agigea harbor, near Constanța [8]. The population was assessed at least once a year since its discovery, during diving sessions. Individuals were measured and surface of the colony assessed using the same methods described in previous studies [8]. 


\section{Results and discussion}

The M. gigas colony found in the Romanian Black Sea is most likely the result of the offshore attempts of acclimating the species to the Black Sea conditions for farming purposes. Since its discovery in 2017, there was no evident growth of the colony, but it has remained stable with living individuals growing. The largest specimen found in 2017 was of $18.6 \mathrm{~cm}$ in length, which suggested that the probable age of the colony was of about 5 years. Until now, no evidence of reproduction was observed in the colony. This year, however, small individuals of less than $5 \mathrm{~cm}$ in length were observed. This indicates that the colony is reproducing and, considering the growing rate of $4-5 \mathrm{~cm}$ in the first year, this shows that they are about one year old [3].
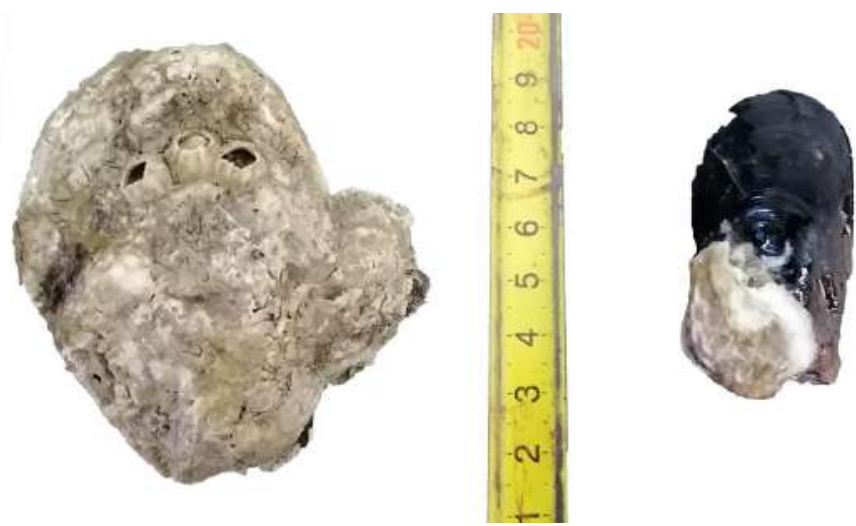

Figure 1. Small $M$. gigä índividuals, of less than $5 \mathrm{~cm}$ in length, found in 2021 attached to other shells in Agigea colony (scale in $\mathrm{cm}$ )

In the context of the global climate change with higher average temperatures, M. gigas has fairly good chances of reproducing and forming stable colonies in the Black Sea. A recent study has also demonstrated that the range expansion of the Pacific oyster is driven by climate warming, predicting its presence all along the Northwest European Shelf [7]. Isolated individuals have been constantly found in the Black Sea even since 1989, and in the last 10 years, wild small populations have started to be found along the eastern, northern and western coasts of the Black Sea [9]. The species seems to follow the same trend in the Bulgarian Black Sea, where more and more specimens are beginning to be found, including small viable colonies of up to 20 individuals [9]. Recently, quite dense young colonies of M. gigas were discovered in the southern Black Sea, along the Turkish coast [1].

The status of $M$. gigas in the Black Sea is not yet clear, as it could fill in an ecosystem niche left empty by the disappearance of the native flat oyster Ostrea edulis or it could affect the present ecosystems in other positive or negative ways. At the moment, according to the framework proposed [2], M. gigas in the Black Sea falls into the C3 category with individuals surviving in locations where introduced with reproduction occurring, and some wild self-sustaining populations. Considering the current climate trends and the high reproductive potential and plasticity 
of the species, M. gigas could easily start establishing secondary colonies in the future and transition to a fully invasive species. The possible impact of the Pacific oyster, with its highly adaptive potential, on the Black Sea ecosystems depends greatly on different complex factors and it is still unknown so far.

\section{Bibliography}

1. Aydın, M., Gül, M. (2021). Presence of the Pacific oyster (Crassostrea gigas Thunberg, 1793) in the Black Sea. Journal of Anatolian Environmental and Animal Sciences, 6(1), 14-17. https:// doi.org/https://doi.org/10.35229/jaes.800160

2. Blackburn, T. M., Pyšek, P., Bacher, S., Carlton, J. T., Duncan, R. P., Jarošík, V., Wilson, J. R. U., Richardson, D. M. (2011). A proposed unified framework for biological invasions. Trends in Ecology \& Evolution, 26(7), 333-339.

https://doi.org/https://doi.org/10.1016/j.tree.2011.03.023

3. Diederich, S. (2006). High survival and growth rates of introduced Pacific oysters may cause restrictions on habitat use by native mussels in the Wadden Sea. Journal of Experimental Marine Biology and Ecology, 328(2), 211-227.

4. Finch, D. M., Butler, J. L., Runyon, J. B., Fettig, C. J., Kilkenny, F. F., Jose, S., Frankel, S. J., Cushman, S. A., Cobb, R. C., Dukes, J. S., Hicke, J. A., Amelon, S. K. (2021). Effects of climate change on invasive species. In T. M. Poland, T. Patel-Weynand, D. M. Finch, C. Ford Miniat, D. C. Hayes, \& V. M. Lopez (Eds.), Invasive Species in Forests and Rangelands of the United States: A Comprehensive Science Synthesis for the United States Forest Sector (pp. 57-84). Springer International Publishing. https://doi.org/https://doi.org/10.1007/978-3-03045367-1_4

5. Gomoiu, M. T., Petran, A. (1973). Les conséquences de l'installation du bivalve Mya arenaria (L.) dans la biocénose des sables fins à Corbula mediterranea (COSTA) du littoral Roumaine de la mer Noire. Rapports et Procès-Verbaux de La Commission Internationale Pour l'étude Scientifique de La Mer Méditerranée, 22(4), 91-92.

6. Grossu, A. V. (1986). Gastropoda Romaniae 1. Caractere generale, istoricul și biologia gastropodelor. Subclasa Prosobranchia și Opistobranchia. Editura Litera.

7. King, N. G., Wilmes, S. B., Smyth, D., Tinker, J., Robins, P. E., Thorpe, J., Jones, L., \& Malham, S. K. (2021). Climate change accelerates range expansion of the invasive non-native species, the Pacific oyster, Crassostrea gigas. ICES Journal of Marine Science, 78(1), 70-81. https://doi.org/10.1093/icesjms/fsaa189

8. Krapal, A.-M., Ioniță, M., Caplan, M., \& Buhaciuc-Ioniţă, E. (2019). Wild Pacific oyster Magallana gigas (Thunberg, 1793) populations in Romanian Black Sea waters - friend or foe? Travaux Du Muséum National d'Histoire Naturelle "Grigore Antipa," 62(2), 175-183.

9. Mitov, P., Uzunova, S., Kenderov, L., Dimov, S., \& Yanachkov, P. (2020). Pacific oyster invasion along Bulgarian Black Sea coast. In Scientific Conference "Kliment's Days", 5th November 2020, Abstracts.

10. Rahel, F. J., \& Olden, J. D. (2008). Assessing the Effects of Climate Change on Aquatic Invasive Species. Conservation Biology, 22(3), 521-533. https://doi.org/https://doi.org/10.1111/ j.1523-1739.2008.00950.x

11. Shiganova, T. A. (2004). Some results of studying the intruder Mnemiopsis leidyi (A.Agassiz) in the Black Sea. In S. P. Volovik (Ed.), Ctenophore Mnemiopsis leidyi in the Black and Azov Seas: Its Biology and Consequences of its Intrusion (pp. 26-68). Turkish Marine Research Foundation. 